\title{
UPAYA PENGUATAN PENDIDIKAN AGAMA ISLAM BERBASIS LITERASI PESANTREN
}

\author{
Ihsan \\ Institut Agama Islam Negeri Kudus, Jawa Tengah, Indonesia \\ Ihsan_dr12@yahoo.co.id
}

\begin{abstract}
Strengthening Islamic Education (PAI) in Madrasah on the basis of Pesantren, can be called conceptual reality. That is, this idea is conceptual. So, what is called a Pesantren-Based Madrasah may not make the institutional unity between madrasah and pesantren. The basic terms in PesantrenBased Madrasah can be conceptual, in which the pesantren's system of values and education systems have become the ontological, epistemological and pedagogical basis of the madrasah education system, without the need to build Pesantren within the madrasah. This paper describes how the idea to Strengthening of Islamic education based on Islamic boarding school literacy, and explains how the conceptual crisis of Islamic Education in schools / madrasah that is further away from the value system and salafi Islamic education culture, a conceptual solution pesantren literacy based is offered to the right Islamic Education. Based on the observations, it was produced that one of the manifestations of strengthening Islamic Education in schools / madrasas based on Islamic boarding schools was the re-formulation of the Islamic Education curriculum in schools / madrasah using the pesantren pattern.
\end{abstract}

Keyword: Islamic Education, Madrasah based Pesantren, Pesantren Literacy. 


\begin{abstract}
Abstrak
Penguatan Pendidikan Agama Islam (PAI) pada Madrasah dengan basis Pesantren, bisa disebut sebagai realitas konseptual. Artinya, gagasan ini bersifat konseptual. Sehingga apa yang disebut sebagai Madrasah Berbasis Pesantren bisa saja tidak menjadikan kesatuan kelembagaan antara madrasah dan pesantren. Term basis dalam Madrasah Berbasis Pesantren bisa bersifat konseptual, di mana sistem nilai dan sistem pendidikan pesantren telah dijadikan basis ontologis, epistemologis dan pedagogis dari sistem pendidikan madrasah, tanpa harus ada pembangunan pesantren di dalam madrasah. Tulisan ini mendeskripsikan bagaimana gagasan pengauatan Pendidikan Agama Islam berbasis literasi pesantren, dan menjelaskan bahwa karena krisis konseptual Pendidikan Agama Islam di sekolah/madrasah yang semakin jauh dari sistem nilai dan kultur pendidikan Islam salafi maka ditawarkan solusi konseptual bahwa Pendidikan Agama Islam yang tepat adalah berbasis literasi pesantren. Berdasarkan observasi terlibat maka dihasilkan bahwa salah satu wujud dari penguatan Pendidikan Agama Islam di sekolah/madrasah yang berbasis literasi pesantren adalah perumusan ulang kurikulum Pendidikan Agama Islam yang ada di sekolah/madrasah dengan menggunakan pola pesantren.
\end{abstract}

Kata kunci: pendidikan agama Islam,madrasah berbasis pesantren, literasi pesantren.

\title{
A. Pendahuluan
}

Pendidikan Agama Islam sebagai salah satu bidang studi yang dapat dijadikan sebagai sarana untuk menghaluskan nilai rasa, moral, watak dan tingkah laku manusia entitasnya ke depan akan semakin terasa penting seiring dengan akselerasi perkembangan peradaban manusia. ${ }^{1}$ Kesiapan langkah preventif atas kemerosotan moralitas islami peserta didik dan problematika Pendidikan Agama Islam di sekolah sekarang ini belum banyak dilakukan rekonstruksi

${ }^{1}$ Suharyanta, Strategi Pembelajaran Pendidikan Agama Islam Di Sekolah, ed. Khamdan (Yogyakarta: Idea Press, 2012), 4. 
baik secara struktural maupun secara fungsional oleh guru pedidikan agama Islam maupun para pembuat kebijakan. Akibatnya Pendidikan Agama Islam di sekolah tidak lebih hanyalah seperti sebuah rutinitas dalam rangka suplemen kegiatan pembelajaran yang rasanya tidak memiliki fungsi yang begitu penting. ${ }^{2}$

Pembelajaran Pendidikan Agama Islam bukan sekedar "transfer of knowledge" ataupun "transfer of training" tetapi lebih kepada suatu sistemyang ditata di atas pondasi keimanan dan kesalehan, suatu sistem yangterkait langsung dengan Tuhan. Menurut Syed Sajjad Husain dan Syed Ali Ashraf Pendidikan Agama Islam diharapkan mengantarkan manusia pada perilaku danperbuatan manusia yang berpedoman pada syariat Allah. ${ }^{3}$ Sehingga dalampelaksanaan pembelajaran Pendidikan Agama Islam tidak sekedar mengajarkan bagaimana caranya shalat, wudlu dan lain-lainya. Lebih dari itu, perlu pengamalan dalam kehidupan sehari-hari agar membekas bahkan menyatu dalam diri. Hal ini tentunya menjadikan Pendidikan Agama Islam tidak cukup hanya diajarkan dalam tiga jam seminggu. Selain itu problem dan sekaligus menjadi kegelisahan adalah masih rendahnya output atau kemampuan dan kompetensi keagamaan (penguasaan pengetahuan agama Islam), sehingga ciri khas Islam sebagai identitas dan jati diri menjadi tidak atau kurang kelihatan secara maksimal. ${ }^{4}$

Berdasarkan uraian di atas, tulisan ini mengkonsepsikan perlu dilakukan upaya yang simultan untuk menguatkan Pendidikan Agama Islam sehingga tujuan Pendidikan Agama Islam yang diharapkan dapat tercapai dengan baik. ${ }^{5}$ Untuk mengatasi rendahnya kemampuan atau kompetensi keagamaan tersebut diperlukan usaha kesadaran akan pentingnya berliterasi

${ }^{2}$ Mustofa Rembangy, Pendidikan Transformatif: Pergulatan Kritis Merumuskan Pendidikan Di Tengah Pusaran Arus Globalisasi (Yogyakarta: Teras, 2008), 225.

${ }^{3}$ Syed Sajjad Husain and Syed Ali Ashraf, Krisis Pendidikan Islam, trans. Rahmani Astuti (Bandung: Risalah, 1986), 2.

${ }^{4}$ Muhaimin, Paradigma Pendidikan Agama Islam Upaya Mengefektifkan Pendidikan Agama Islam (Bandung: Remaja Rosdakarya, 2004), 75-76.

${ }^{5}$ Soetomo, Dasar-Dasar Interaksi Belajar Mengajar (Surabaya: Usaha Nasional, 1993), 96. 
dan penerapan desain dan atau implementasi program Pendidikan Agama Islam yang memungkinkan penguatan kembali Pendidikan Agama Islam yang maksimal.

\section{B. Pembahasan}

\section{Konsep Penguatan Berbasis Literasi Pesantren}

"Literasi" berasal dari bahasa Inggris yaitu literacy. Literasi juga berasal dari bahasa latin yaitu littera artinya hurut yang pengertianya melibatkan penguasaan sistem-sistem tulisan dan juga konvensi-konvensi yang menyertainya. Sekarang ini literasi bukan hanya diartikan sebagai kemampuan membaca dan menulis saja melainkan "...has instead come to be consisdered synonymous with its hoped-for consequences". 6

Literasi diartikan sebagai kemampuan peserta didik dalam "melek wacana". Keterampilan awalnya menekankan pada pengembangan kompetensi menulis dan membaca. Setelah itu pengembangannya merupakan bentuk integrasi dari kemampuanmendengarkan, berbicara, memirsa, membaca, menuis, dan berpikir kritis. Kemampuan literasi (membaca dan menulis) merupakan fondasi atau dasar penentu keberhasilan dalam kegiatan belajar peserta didik. ${ }^{7}$ Kemapuan literasi di kelas awal ini dianggap sebagai prasyarat yang mendasari penguasaan kemampuan lainnya. Karena itu, pembelajaran membaca dan menulis di kelas awal perlu mendapat perhatian serius. Berdasarkan uraian tersebut, istilah literasi merupakan sesuatu yang terus berkembang atau terus berproses, yang pada intinya adalah pemahaman terhadap teks dan konteksnya sebab manusia berurusan dengan teks sejak dilahirkan, masa kehidupan, hingga kematian. Keterpahaman terhadap beragam teks akan membantu keterpahaman kehidupan

${ }^{6}$ M. Aronoff, "Spelling as Culture," in Writing System And Cognition : Perspectives from Psychology, Physiology, Linguistics, and Semiotics (Dordrecht: Kluwer Academic, 1994), 68.

${ }^{7}$ Sri Triatri, Bunga Rampai Psikologi Dari Anak Sampai Usia Lanjut BAB II Perkembangan Pemahaman Bacaan (Jakarta: Gunung Mulia, n.d.), 45. 
dan berbagai aspeknya karena teks itu representasi dari kehidupan individu dan masyarakat dalam budaya masing-masing. ${ }^{8}$

Budaya membaca berbanding lurus dengan tingkat kemajuan pendidikan suatu bangsa. Kegiatan membaca merupakan hal yang sangat penting bagi kemajuan suatu bangsa. Parameter kualitas suatu bangsa dapat dilihat dari kondisi pendidikannya. Pendidikan selalu berkaitan dengan kegiatan belajar. Belajar selalu identik dengan kegiatan membaca karena dengan membaca akan bertambahnya pengetahuan, sikap dan keterampilan seseorang. Pendidikan tanpa membaca bagaikan raga tanpa roh. Fenomena, pengangguran intelektual tidak akan terjadi apabila masyarakat memiliki semangat membaca yang membara. Membaca dan menulis adalah keterampilan yang saling melengkapi. Tidak ada yang perlu ditulis kalau tidak ada yang membacanya, dan tidak ada yang dapat dibaca kalau belum ada yang ditulis. Ada pepatah yang mengatakan untuk mengenal dunia maka membacalah, dan untuk dikenal dunia maka menulislah. Pepatah ini mengingatkan kita bahwa betapa pentingnya arti tulisan bagi seseorang. Dengan demikian, literasi dianggap sebagai budaya dan proses habituasi yang urgen dalam pembangunan bangsa. Literasi memiliki nilai dalam meningkatkan kualitas hidup. Literasi digunakan sebagai indikator keberhasilan pendidikan dan pembangunan. Negara yang dianggap maju pada umumnya memiliki tingkat literasi yang tinggi. ${ }^{9}$

Saat ini, kegiatan di sekolah atau madrasah ditengarai belum optimal mengembangkan kemampuan literasi warga sekolah. Hal ini disebabkan, antara lain oleh minimnya pemahaman warga sekolah atau madrasah terhadap pentingnya kemampuan literasi dalam kehidupan mereka serta minimnya penggunaan buku-buku di sekolah (selain buku-teks pelajaran). Kegiatan membaca di

${ }^{8}$ Direktorat Pembinaan SMK \& Direktorat Jenderal Pendidikan Dasar dan Menengah, Materi Pelatihan: Strategi Literasi Dalam Pembelajaran Di SMK (Jakarta: Kemendikbud, 2017), 1-2.

${ }^{9}$ Lizamudin Ma’mur, Membangun Budaya Literasi: Meretas Komunitas Global (Jakarta: Diadit Media, 2010), 111. 
sekolah masih terbatas pada pembacaan buku teks pelajaran dan belum melibatkan jenis bacaan lain.

Secara umum memang ada perbedaan kajian literasi yang digunakan antara sekolah umum dengan madrasah yang merupakan sekolah formal berciirikan Islam. Literasi kajian keagamaan yang ada di madrasah lebih banyak dibandingkan dengan sekolah umum, terutama di bidang keagamaan. Mata pelajaran Pendidikan Agama Islam (PAI) di SMU diberikan dalam satu paket mata pelajaran yang diajar oleh satu guru yang disebut dengan guru agama, sedangkan di madrasah dijabarkan ke dalam empat mata pelajaran, yaitu: (1) Qur'an-Hadits, (2) Aqidah Akhlak, (3) Fiqh, dan (4) Sejarah Kebudayaan Islam

Beberapa madrasah swasta yang memiliki visi dan orientasi keagamaan kuat (tafaqquh fi al-din - Salaf) membedakan secara tegas ilmu-ilmu tersebut ke dalam beberapa bidang. Bahkan ada madrasah yang mengelompokkan atau membedakan ilmu yang menjadi materi ajarnya ke dalam empat bidang, yaitu: al-'Ulum al-Shari'ah (Ilmu-Ilmu Syari'ah/hukum), al-'Ulum al-Lug\}awiyyah (Ilmu-Ilmu Bahasa), al-'Ulum al-Thaqafah (ilmu-ilmu sosial budaya), al-'Ulum al-Riyadiyyah (ilmu-ilmu pasti). Masing-masing kelompok ilmu tersebut dijabarkan menjadi beberapa ilmu/mata pelajaran. Sementara beberapa madrasah yang lain membedakan dan mengelompokkan ilmu yang diajarkan sesuai pembidangan yang ditetapkan Depertemen Agama, dengan penambahan beberapa mata pelajaran agama.

Meskipun berpedoman dan menggunakan kurikulum Kementerian Agama, namun pembelajaran bidang PAI di madrasah jenis ini tidak menggunakan buku teks yang ditetapkan oleh Kementerian Agama. Hal ini dilakukan karena para pengelola madrasah memandang isi/bobot kurikulum tersebut dianggap terlalu ringan, terutama bila dikaitkan dengan orientasi akademik, visi-misi, dan kompetensi yang ingin dicapai madrasah tersebut. Secara tegas dinyatakan bahwa kompetensi lulusan madrasah kategori ini adalah kemampuan membaca teks/kitab Berbahsa 
Arab (kitab kuning). Kemampuan membaca kitab kuning ini justru dianggap sebagai keunggulan dan sekaligus menjadi daya tarik tersendiri bagi mayoritas orang tua siswa. Dalam banyak hal, madrasah ini substantif sama persis dengan pondok pesantren, baik kompetensi, sistem pembelajaran bidang studi agama Islam, maupun kultur dan suasana madrasah. Sehingga tidak berlebihan kalau madrasah ini sesungguhnya adalah pesantren yang menggunakan sistem klasikal dan model penjenjangan, dua hal yang menjadi ciri pokok sistem persekolahan. Dalam komunitas santri (pesantren), istilah kemampuan membaca memiliki konotasi kebahasaan yang berbeda dengan kemampuan membaca dalam bahasa lain, bahasa Inggris umpamannya. Istilah kemampuan membaca di sini tidak dalam pengertian ability to read dan to understanding saja, tetapi secara teknis kebahasaan berbeda. Dalam tata tulis bahasa Arab dikenal adanya tanda baca (harakah) yang berfungsi tidak hanya membantu orang untuk membaca saja tapi lebih dari itu adalah untuk menunjukkan gramatika dan stuktur kata dalam suatu kalimat. Teks klasik (kitab kuning) semuanya dalam bentuk tulisan yang tidak ada harakatnya, untuk membaca dan sekaligus memahami arti dan maknanya maka seseorang harus menguasai beberapa ilmu alat (ilmu bantu) tentang hal tersebut, antara lain ilmu Nahwu. Jadi dalam bahasa Arab seseorang tidak akan bisa membaca dan memahami makna suatu kata atau kalimat manakala tidak menguasai ilmu-ilmu alat (bantu) yang terkait dengan struktur kalimatatau teknis kebahasaan yang lain.

Beberapa madrasah ada penambahan mata pelajaran agama Islam untuk pendalaman dan pengayaan, namun pada dataran praktis terdapat perbedaan dalam model dan intensitas pembelajaran yang berujung pada perbedaan kompetensi yang dicapai. Perbedaan kompetensi inilah yang kemudian menjadi karakter pembeda antara madrasah satu dengan yang lain. Contoh: bagi MA yang mampu, pendalaman mata pelajaran Qur'an-Hadits diberikan dalam bentuk pengajaran kitab Tafsir Jalalayn dan S\} ahih Bukhari, dan masih ditambah dengan beberapa ilmu bantu 
terkait dengan bidang tersebut, seperti 'Ulum al-Qur'an dan 'Ulum al-Hadith dan lain-lain. Pembelajaran beberapa mata pelajaran tersebut diberikan dengan menggunakan teks klasik (kitab kuning) dengan sistem pembelajaran seperti di pesantren. Sementara untuk madrasah yang kurang mampu penambahan mata pelajaran tersebut diberikan dalam format yang lebih sederhana, untuk pelajaran Quran hanya sekedar kutipan tafsir ayat-ayat tertentu, atau untuk hadits hanya beberapa hadits tertentu. Tujuan yang ingin dicapai dari pembelajaran ini adalah untuk penambahan pengetahuan agama Islam dengan kualifikasi tidak mendalam. Karena berbagai kendala pada siswa, biasanya para guru membuat diktat atau rangkuman materi dengan format yang lebih sederhana yang penting siswa paham isinya.

Sesuai signifikansinya dengan pencapaian kompetensi PAI, beberapa kitab yang dijadikan bahan literasinya, meliputi: (1) alQur'an, yang terdiri dari 'Ulum al-Qur'an dan Tafsir al-Qur'an, (2) Hadis, yang terdiri dari Ulum al-Hadithdan Sharah Hadith, (3) Fiqih, yang meliputi Qowaid al-Fiqh dan Ușul al-Fiqh. Khusus untuk materi Aqidah-Akhlak dan Sejarah Kebudayaan Islam, tidak harus diberikan dalam bentuk pengajaran kitab kuning, tapi bisa diberikan dalam bentuk teks yang lebih sederhana, yang penting para siswa memahami makna dan pengertian tema-tema utama dari materi tersebut. Namun demikian, pemberian dalam bentuk bahasa Arab bila memungkinkan bisa diberikan. Dengan strategi ini, maka pembelajaran di madrasah akan terhindar dari kurikulum yang sarat muatan karena banyaknya mata pelajaraan yang harus diberikan.

Hal inilah yang membedakan kuantitas dan kualitas literasi dalam Pendidikan Agama Islam antara sekolah umum dengan madrasah, pada posisi ini madrasah memiliki keunggulan, karena disamping pengajaran agama sesuai kurikulum nasional ditambah dengan pengayaan pelajaran-pelajaran agama dengan menggunakan kitab-kitab salaf, bahkan sampai pada kompetensi membaca kitab kuning. Ini merupakan salah satu bentuk upaya lembaga 
pendidikan khususnya madrasah dalam memberikan penguatan Pendidikan Agama Islam dengan model literasi pesantren.

\section{Pendidikan Agama Islam Berbasis Literasi Pesantren}

Penguatan Pendidikan Agama Islam berbasis literasi pesantren sebenarnya adalah cara mujarab untuk memajukan madrasah. Memang ada keunikan pesantren yang meliputi; tingkah laku, tata nilai, dan hirarki kepemimpinan. Model uniqueness pada literasi berbasis pesantren adalah: Pertama, pengaturan waktu. Kegiatan literasi pesantren utamanya pada pengajian kitab kuning ditempatkan pada waktu khusus, misalnya setelah melaksanakan sholat wajib lima waktu (shalat rawatib). Maksud penguatan literasi ini adalah bahwa kegiatan literasi akan tercipta karena diikutkan/ disatukan dengan kewajiban. Harapannya kegiatan literasi tersebut akan menjadi kegiatan yang simultan dan menyatu seperti suatu kewajiban. Dari kewajiban yang terkondisi tersebut diharapkan ke depan menjadi sebuah budaya. Dimensi literasi pesantren yang unik juga adalah terlihat pada lamanya masa belajar di pesantren. Selama seorang santri masih memerlukan bimbingan pengajian dari kyainya, selama itu pula ia tidak merasakan keharusan untuk mengakhiri masa belajar di pesantren.

Kedua, struktur pengajaran. Dalam hal ini sistematika pengajaran dipesantren dapat dijumpai dengan pola adanya jenjang pelajaran yang berulang dari tingkat ke tingkat. Hanya saja kekurang efisien yang ada di pesantren adalah tiadanya target waktu pembelajaran atau tanpa terlihat kesudahannya. Penguatan Pendidikan Agama Islam dalam konteks ini adalah bahwa adanya pengulangan materi yang bersifat penjabaran. Materi yang diajarkan sering kali pembahasan serupa yang diulang-ulang meskipun dengan buku teks yang berlainan, dimulai dengan "kitab kecil" (mabsutah) yang berisi teks ringkas sederhana, lalu materi itu akan dijabarkan atau uraiakan dengan lebih luas penjelasannya pada "kitab sedang" (mutawassitah). Di samping hal tersebut, bahwa saat mengikuti pengajian atau pembelajarn ala pesantren tersebut 
ada niat semoga ada keberkahan yang diberikan oleh Allah melalui mengkaji kitab tersebut.

Ketiga, Penguatan Pendidikan Agama Islam berbasis literasi pesantren adalah dengan memberikan pengayaan pembelajaran dengan model klasikal sekaligus digabungkan dengan model sorogan. Pelajaran diberikan dalam pengajian yang berbentuk kuliah terbuka, di mana sang kiai membaca, menerjemahkan, untuk kemudian menerangkan persoalan yang disebut dalam teks tersebut. Para santri kemudian membaca ulang teks itu, entah dihadapan kiai, atau setelah kembali ke bilik, atau dalam pengajian ulang antara sesama santri semisal musyawarah, tikrar, mudarasah, jam'iyyah, dan sebagainya. Pada titik inilah, pelajaran di pesantren kemudian membentuk tata nilai dan pandangan hidup kaum santri. ${ }^{10}$

Ciri terakhir dari sub-kultur pesantren adalah hirarki kepemimpinan kiai. Gaya kepemimpinan ini terutama berciri hubungan guru-murid yang ketat dan intens, berdasarkan doktrin emanasi (al-faid) sufi. Menurut doktrin ini, keagungan Allah memancar dari wajah-Nya, sebagai Cahaya Sejati (al-nur), dan membekas pada tipe-tipe orang tertentu, seperti guru-guru tadi. Dengan berkhidmat kepada para kiai, serta mencontoh cara hidup mereka dari dekat, para santri akan memperoleh keagungan pula, sehingga kelak mereka dapat menjadi kiai. Kepemimpinan tersebut ditegakkan di atas kewibawaan moral sang kyai sebagai penyelamat para santri dari kemungkinan melangkah ke arah kesesatan. ${ }^{11}$ Dengan demikian, penguatan Pendidikan Agama Islam berbasis literasi pesantren pada konteks ini adalah adanya hierarkhi gurumurid, sehingga dengan hirarki ini moral dan akhlak murid dapat terjaga dalam perkembangannya. Guru minimal bisa sebagai sumber inspirasi dan penunjang moral.

${ }^{10}$ Abdurrahman Wahid, "Principle of Pesantren Education," in The Pesantren Education Seminar (Berlin: FNS, 1987), 4.

${ }^{11}$ Martin van Bruinessen, Kitab Kuning, Pesantren Dan Tarekat: TradisiTradisi Islam Di Indonesia (Bandung: Mizan, 1999), 13. 
Dalam rangka penguatan Pendidikan Agama Islam tersebut model pengelolaan madrasah sesuai dengan konteks atau karakteristik problem yang dihadapi adalah solusinya. Model literasi pesantren ini adalah: Pertama, madrasah menerapkan model boarding school (asrama) dengan mengadopsi konsep sistem "pondok" atau pemondokan bagi para santri sebagaimana telah lama diterapkan dalam sistem pendidikan pesantren. Unsur esensial yang diadopsi dari sistem ini adalah pada aspek sistem full days school, dimana proses belajar mengajar bisa dilaksanakan tidak hanya pada aspek kurikulum formal saja tetapi juga pada aspek hidden curriculum. Pada model ini, para guru, pembina/pengasuh dimungkinkan untuk melaksanakan kegiatan belajar mengajar dengan menganut prinsip belajar sepanjang hari - sampai sore atau malam hari. Dengan demikian, peluang untuk mencapai tujuan spesifik madrasah menjadi sangat besar, terutama penguasaan ulum al din. Karena pada sistem ini dimungkinkan terjadinya pembelajaran yang lebih terarah, berkualitas, dan memadai. Terarah karena pembelajaran di kelas dan di asrama di desain untuk saling mendukung dan melengkapi untuk mencapai tujuan utama pendidikan madrasah. Berkualitas karena pembelajaran di asrama atau di luar jam sekolah memungkinkan lebih diperdalam dan ditingkatkan. Memadai karena waktu yang tersedia tidak hanya terbatas pada waktu yang dialokasikan di jam belajar di pagi hari saja. Dengan tersedianya waktu yang cukup atau memadai, para pengelola madrasah bisa menggunakan waktu secara maksimal untuk kepentingan mempercepat pencapaian kompetensi bahkan melampaui, termasuk kompetensi spesifik.

Kedua, madrasah membangun pola moral asketisme (zuhud) yang menjadikan kebahagian ruhaniah sebagai tolok ukur dalam menilai sesuatu. Pada konteks ini madrasah mngajarkan melalui Pendidikan Agama Islam sikap, tidak terjebak dalam kecintaan terhadap dunia, ma siwallah dan tidak abai dan lari dari dunia. Karena dunia bukanlah materi di dalam dirinya sendiri, tetapi keterjebakan terhadap ma siwallah, maka seorang muslim boleh kaya asal hatinya tetap untuk Allah. 
Ketiga, madrasah membangun pola satu atap manajemen atau manajemen yang terintegrasi antara pesantren dengan madrasah. Tujuan dari penyatuan sistem pengelolaan ini adalah agar semua proses pendidikan berada dalam suatu sistem yang memungkinkan semua kegiatan guru dan murid berada dalam satu alur dan paket program yang sama. Dengan sistem atau model ini akan tercipta proses pendidikan holistik yang akan melahirkan output dan outcome pendidikan berkualitas.

Keempat, penguatan Pendidikan Agama Islam dapat dilakukan dengan pengelolaan kegiatan ekstra dalam sistem madrasah pesantrendengan fokus pada: pertama, penguatan kemampuan akademis sebagai upaya untuk mendukung pencapaian standar kompetensi lulusan dan kompetensi spesifik keagamaan. Jenis kegiatan yang dapat dilakukan antara lain penambahan jam untuk pembelajaran bidang sains dan/atau ilmu pengetahuan pada umumnya yang diujikan dalam UN, dan untuk mendukung pencapaian kompetensi keagamaan. Kedua, mewujudkan "pendidikan yang dijiwai suasana keagamaan" dengan tujuan utama pembentukan moral yang berdasarkan nilai-nilai keislaman (al-akhlaq al-karimah), melalui pembelajaran pembiasaan dan pendampingan. Format kegiatan ekstra dalam konteks ini bisa dalam bentuk latihan yang berhubungan dengan ritual keagamaan dan kegiatan pengayaan spiritual pada umumnya. Hal yang lebih penting lagi, kegiatan ekstra ini memungkinkan pengkondisian berbagai perilaku mulia yang dapat ditiru dan dilaksanakan oleh peserta didik sebagai wujud implementasi hidden curriculum. Dua kegiatan tersebut hanya dimungkinkan manakala tersedia waktu dan ruang yang cukup untuk dilakukannya kegiatan-kegiatan yang bertujuan untuk penanaman nilai dan keyakinan dalam setiap pembelajaran.

Selain itu semua, ada empat strategi penguatan Pendidikan Agama Islam berbasis literasi pesantren : (1) Internalisasi nilai-nilai ke-Islaman dalam setiap pembelajaran. (2) Membuat slogan-slogan dan berbagai aksesoris yang mampu menumbuhkan kebiasaan baik 
dalam segala tingkah laku dalam komplek asrama/pendidikan. (3) Pemantauan secara kontinyu melalui pendampingan oleh guru/ ustadz setiap saat. Pemantauan ini terkait dengan tiga hal yang terangkum dalam soft competence, yaitu perilaku, konsep diri anak, dan motivasi. (4)Pendampingan pengasuh asrama/pondok dengan memberikan penilaian terhadap perilaku anak selama di asrama sebagai bagian dari proses pendidikan secara integral.

Dengan mengadopsi sistem pesantren ini, secara umum ada empat hal penting yang dapat dicapai atau diperoleh secara simultan oleh madrasah. Capaian ini sekaligus merupakan keunggulan dan kelebihan madrasah bila dibandingkan dengan sekolah umum atau pendidikan Islam tradisional lainnya. Bila hal ini dapat diwujudkan, maka akan tercipta produk (output - outcome) dari proses pendidikan di MA yang sesuai dengan ekspektasi para penggunanya. Empat hal tersebut meliputi: (1) penguatan atau pendalaman 'ulum al-din sebagai upaya untuk meningkatkan kualitas pengetahuan dan keberagamaan peserta didik. (2) Pendalaman materi science (mata pelajaran umum) sebagai upaya untuk mencapai keunggulan komparatif sejalan dengan arus besar kebijakan pendidikan nasional. (3) Pemberian latihan ketrampilan untuk memberi bekal life skill sebagai bekal bagi lulusan untuk terjun dalam kehidupan bermasyarakat dengan keunggulan kompetitif. (4) Optimalisasi kegiatan ekstra dalam rangka mewujudkan "pendidikan yang dijiwai dengan suasana keagamaan".

Atas dasar berbagai pertimbangan tersebut, maka model madrasah berbasis pesantren ini menjadi tempat yang paling paling memungkinakn untuk tercapainya kompetensi plus. Hal ini dimungkinkan karena interaksi pembelajaran berlangsung dalam durasi waktu yang cukup, baik melalui kurikulum formal maupun hiden curriculum. Ketersediaan waktu inilah yang memungkiankan untuk melaukan pembelajaran penguatan, tidak hanya PAI tetapi untuk pengetahauan dan keterampilan yang lain relevan dan dibutuhkan. Dilihat dari sudut materi atau bahan, model penguatan 
ini dapat dikelopokkan menjadai dua macam, yaitu (1) penguatan materi PAI kurikuler, dan (2) penguatan PAI dengan nilai dan spirit pesantren.

Pertama, penguatan PAI melalui pengayaan. Penguatan PAI yang dimaksud disini adalah penguatam mata pelajaran agama yang tergabung dalam rumpun PAI. Selama ini pembelajaran empat mata pelajaran tersebut dari sudut hasil/penguasaan pengetahuan agama dipandang kurang memadai. Oleh karenanya perlu penambahan jam pelajaran dalam rangka memperdalam (pendalaman) penguasaan PAI tersebut melalui program pengayaan. Kedua, penguatan PAI melalui kokurikuler maupun ekstra kurikuler.

\section{Kesimpulan}

Pendidikan Agama Islam sebagai salah satu bidang studi yang dapat dijadikan sebagai sarana untuk memperbaiki moral, watak dan tingkah laku manusia entitasnya ke depan akan semakin terasa penting seiring dengan perkembangan peradaban manusia. Sebagai langkah atas kemerosotan moralitas tersebut salah satunya melalui Pendidikan Agama Islam di sekolah. Sekarang ini belum dilakukan rekonstruksi baik secara struktural maupun secara fungsional oleh guru pedidikan agama Islam maupun para pembuat kebijakan. Akibatnya Pendidikan Agama Islam di sekolah tidak lebih hanyalah seperti sebuah rutinitas dalam rangka suplemen kegiatan pembelajaran.

Untuk mengatasi permasalahan tersebut, diperlukan penguatan Pendidikan Agama Islam, karena agama memegang peran penting dalam memperbaiki tingkah laku manusia. Salah satu bentuk upaya penguatan yang dapat ditempuh adalah dengan mengimplementasikan konsep penguatan berbasis literasi pesantren sebagaimana telah dilaksanakan di beberapa madrasah yang merupakan sekolah umum yang bercirikan Islam.

Desain Pendidikan Agama Islam pada madrasah didasarkan kepada spirit dan nilai kepesantrenan sebagai bagian utama dari 
tradisi Islam dan sekaligus memenuhi kualifikasi standar nasional pendidikan. Pola pembelajaran tekstualis yang digunakan dalam pembelajaran yang merujuk pada kajian literatur kitab kuning. Yakni pembelajaran atas karya-karya ulama klasik dalam bidang tafsir, fiqh, tasawuf, hadist, dan tarikh (sejarah). Pola ini yang melahirkan pembelajaran khas pesantren, yang secara instrinsik memuat pula pembelajaran dan penguasaan atas ilmu-ilmu 'alat kebahasaan Arab. Dengan pola tekstualis ini, para pelajar Islam secara otomatis dididik dalam keketatan tekstual atas sumbersumber utama pengetahuan Islam yang tentunya berbahasa Arab, dengan standar penguasaan atau bahkan penghapalan atas teks klasik itu, secara detail, rigid, dan tekstualis. Dengan cara ini, para pelajar Islam akhirnya menjadi para pewaris utama khasanah pengetahuan dan peradaban klasik Islam yang mengakar pada sumber-sumber awal dan utama dari pengetahuan Islam. 


\section{DAFTAR PUSTAKA}

Alwasilah, A. Chaedar. Membangun Kota Berbudaya Literat. Jakarta: Media Indonesia, 2001.

Aronoff, M. “Spelling as Culture.” In Writing System And Cognition : Perspectives from Psychology, Physiology, Linguistics, and Semiotics. Dordrecht: Kluwer Academic, 1994.

Bruinessen, Martin van. Kitab Kuning, Pesantren Dan Tarekat: Tradisi-Tradisi Islam Di Indonesia. Bandung: Mizan, 1999.

Direktorat Pembinaan SMK \& Direktorat Jenderal Pendidikan Dasar dan Menengah. Materi Pelatihan: Strategi Literasi Dalam Pembelajaran Di SMK. Jakarta: Kemendikbud, 2017.

Farmer, Lesley S.J, and James Henri. Information Literacy Assessment in K-12 Setting. Maryland: Scarecrow Press, 2008.

Husain, Syed Sajjad, and Syed Ali Ashraf. Krisis Pendidikan Islam. Translated by Rahmani Astuti. Bandung: Risalah, 1986.

Ma'mur, Lizamudin. Membangun Budaya Literasi: Meretas Komunitas Global. Jakarta: Diadit Media, 2010.

Muhaimin. Paradigma Pendidikan Agama Islam Upaya Mengefektifkan Pendidikan Agama Islam. Bandung: Remaja Rosdakarya, 2004.

Perpustakaan Nasional RI. Pedoman Pembinaan Minat Baca. Jakarta: Perpustakaan Nasional RI, 2007.

Rembangy, Mustofa. Pendidikan Transformatif: Pergulatan Kritis Merumuskan Pendidikan Di Tengah Pusaran Arus Globalisasi. Yogyakarta: Teras, 2008.

Samani, Muchlas. Profesionalisasi Pendidikan. Surabaya: UNESA University Press, 2012.

Soetomo. Dasar-Dasar Interaksi Belajar Mengajar. Surabaya: Usaha Nasional, 1993.

Suharyanta. Strategi Pembelajaran Pendidikan Agama Islam Di Sekolah. Edited by Khamdan. Yogyakarta: Idea Press, 2012. 
Triatri, Sri. Bunga Rampai Psikologi Dari Anak Sampai Usia Lanjut BAB II Perkembangan Pemahaman Bacaan. Jakarta: Gunung Mulia, n.d.

Wagner, Tony. The Global Achievement Gap: Why Even Our Best Schools Don't Teach The Survival Skills Our Children Need and What We Can Do About It. New York: Basic Books, 2008.

Wahid, Abdurrahman. "Principle of Pesantren Education." In The Pesantren Education Seminar. Berlin: FNS, 1987. 
